\title{
Peroxidase isoenzyme gradients in Capsicum annuum leaves and their expression in vegetative and flowering plants
}

\author{
MA Bernal ${ }^{1}, J^{D} D_{i a z}{ }^{1}, A$ Ros Barceló ${ }^{2 *}, F$ Merino de Cáceres ${ }^{1}$ \\ ${ }^{1}$ Department of Plant Biology, Faculty of Sciences, University of La Coruña, E15071 La Coruña; \\ ${ }^{2}$ Department of Plant Biology (Plant Physiology), University of Murcia, E30100 Murcia, Spain
}

(Received 5 October 1993; accepted 24 January 1994)

\begin{abstract}
Summary - The expression of peroxidases (EC 11117) during leaf development has been studied by horizontal discontinuous starch-gel electrophoresis in vegetative and flowering plants of Capsicum annuum (var annuum) to assess the nature, subcellular localization and gradients of the peroxidase isoenzymes that characterize the floral state determining the beginning of reproductive development. The results showed that the development of the leaves in both vegetative and flowering plants is accompanied by a significant increase in the level of the peroxidase isoenzyme group prx a, similar to that found along the aging axis of the stem and, therefore, non-organ-specific. An analysis of the subcellular localization of the peroxidase isoenzyme group prx $a$ in flowering plants showed that this isoenzyme group is mainly located bound ionically to cell walls. These results differ from those obtained previously by isoelectric focusing, in which no peroxidase isoenzyme changes were found as a consequence of leaf development. These results, and the fact that $\alpha$-mannosidase increases in free spaces of the cell wall as a consequence of leaf development, suggest that the expression of the peroxidase isoenzyme group prx a may be caused by differences in the terminal $\alpha$-linked mannose residues of the previously existing peroxidase iso-glycoproteins.
\end{abstract}

Capsicum annuum $=$ pepper/vegetative and flowering plants/peroxidase gradient/cell-wall free space

Résumé - Gradients d'isoenzymes des peroxidases dans les feuilles de Capsicuum annuum et leur expression dans les plantes végétatives et en fleurs. L'expression des peroxydases (EC 11117) au cours du développement a été étudiée par électrophorèse horizontale discontinue sur gel d'amidon chez des plantes à l'état végétatif et à l'état reproducteur de Capsicum annuum (var annuum) pour évaluer la nature, la localisation subcellulaire et les gradients des enzymes des peroxydases qui caractérisent l'état floral déterminant le début du développement reproducteur. Les résultats montrent que le développement des feuilles est accompagné tant chez les plantes végétatives que chez celles qui fleurissent par une augmentation significative du groupe d'isoenzymes des peroxydase prx a, qui est analogue à celui qu'on trouve le long de l'axe de la tige, donc non spécifique d'un organe. L'analyse de la localisation subcellulaire du groupe prx a d'isoenzymes des peroxydases chez les plantes fleuries montre que les enzymes de ce groupe sont principalement localisées sous forme liée aux parois cellulaires, probablement en équilibre avec celles qui circulent librement dans les espaces intercellulaires. Ces résultats sont différents de ceux précédemment obtenus par focalisation isoélectrique, suivant lesquels il n'y avait pas de changement lié au développement des feuilles. Ces résultats, et le fait que la $\alpha$-mannosidase augmente dans les espaces intercellulaires, suggèrent que l'expression des isoenzymes des peroxydases du groupe prx a peut être due à des différences dans les résidus terminaux de mannose en liaison $\alpha$ des iso-glycoprotéines peroxydases qui pré-existaient. Capsicum annuum = poivron $/$ plantes végétatives et en fleurs $/$ gradients des peroxidases/espace
intercellulaire

*Correspondence and reprints 


\section{INTRODUCTION}

Pepper (Capsicum annuum var annuum) is an annual plant of great agronomic interest due to the nutritional value of the fruit. The formation of the seeds is the last step in the reproductive development of Capsicum annuum. Reproductive development in plants involves the promotion of meristematic activity in floral buds and its concomitant suppression in vegetative buds, which leads to a different growth pattern of the flowering plant (Zeevaart, 1976; Bernier, 1988).

Indole-3-acetic acid (IAA) is the main regulator of vegetative growth in plants. Since peroxidase (EC 11117) participates in the homeostasis of IAA through its catabolism (Ros Barceló and Muñoz, 1992), it is not surprising that the regulation of peroxidase expression and its localization in leaves of vegetative plants differs from that of flowering plants (Bernal et al, 1993). Thus, changes in peroxidase activity and isoenzyme patterns have frequently been shown to take place during the transition of plants from the vegetative to the reproductive state (Thorpe et al, 1978; Kay and Basile, 1987; Goto and Hamada, 1988; Greppin et al, 1990). An increase in peroxidase activity was invariably observed, accompanied in most cases by the specific expression of several peroxidase isoenzymes, which are sometimes considered as markers of plant differentiation and morphogenesis (Kahlem, 1975; Trinh et al, 1981), although in many cases the specific expression of peroxidase isoenzymes may result from modifications in the asparagine-linked glycans of the peroxidase glycoprotein (Driouich et al, 1989).

However, the above-cited peroxidase responses have not been studied in depth as regards the nature and subcellular localization of the newly expressed peroxidase isoenzymes. With this in mind, the present study was undertaken in an attempt to understand the isoenzyme gradients of apoplastic peroxidase in Capsicum annuum leaves and their nature in vegetative and flowering plants. For comparative purposes, peroxidase isoenzyme gradients in stems are also reported.

\section{MATERIALS AND METHODS}

\section{Plant material}

Seeds of Capsicum annuum (var annuum) were collected from mature fruits and germinated on moistened filter paper in Petri dishes. The plantlets were transferred to pots and grown in a greenhouse with a $16 \mathrm{~h}$ photoperiod at $25^{\circ} \mathrm{C}$ until flowers appeared (Bernal et al, 1993). Stem segments $(1.0 \mathrm{~cm})$ and pairs of leaves beneath the apex from the first, second, third and fourth internodes from vegetative (1-month-old) and flowering (3-months-old) plants were used for the studies.

\section{Tissue homogenization}

Stem segments and leaves from vegetative and flowering plants were homogenized at $4{ }^{\circ} \mathrm{C}$ with a mortar and pestle in $0.2 \mathrm{M}$ sodium phosphate buff$\mathrm{er}, \mathrm{pH}$ 6.1. The homogenate was immediately squeezed through one layer of cellulose gauze and centrifuged at $25000 \mathrm{~g}$ for $15 \mathrm{~min}$. The supernatant constituted the soluble fraction used in further studies.

\section{Isolation of cell-wall enzymes}

Seven $\mathrm{mm}$ external diameter disks from leaves were rinsed with $50 \mathrm{mM}$ Tris $-\mathrm{HCl}, \mathrm{pH} 7.6$, and vacuum infiltrated for $10 \mathrm{~min}$ in the above buffer with or without $100 \mathrm{mM} \mathrm{CaCl}_{2}$. The cell-wall fluid was recovered after centrifuging the infiltrated leaf disks at $1000 \mathrm{~g}$ for $5 \mathrm{~min}$ at $4^{\circ} \mathrm{C}$ (Rathmell and Sequeira, 1974; Bernal et al, 1993). Contamination of the fluid from the free space of the cell wall by cytosolic sap was assayed using glucose6-phosphate dehydrogenase as an enzyme marker; cytosol contamination of the same solution recovered by centrifugation was in all cases of the order of $0.1 \%$. The peroxidase activity bound to cell walls was calculated by subtracting the peroxidase activity extracted with buffer alone from those extracted with buffer containing $\mathrm{CaCl}_{2}$.

\section{Measurement of enzymatic activity}

Peroxidase (EC 11117) activity was estimated at $25^{\circ} \mathrm{C}$ with guaiacol according to Takahama and Egashira (1991). Glucose-6-phosphate dehydrogenase (EC 11149 ) was measured as reported by Ros Barceló et al (1991), while $\alpha$-mannosidase (EC 32124 ) was measured as reported by Boller and Kende (1979). Enzymatic activities, expressed as katal for all the assayed enzymes, were defined as the amount of enzyme that converts one $\mathrm{mol} \cdot \mathrm{s}^{-1}$ of substrate into product.

\section{Electrophoresis and staining of peroxidase isoenzymes}

Horizontal discontinuous starch-gel electrophoresis and staining of peroxidase isoenzymes with $o$ dianisidine were carried out according to Merino de Cáceres and Bernal (1992). 


\section{RESULTS AND DISCUSSION}

\section{Peroxidase isoenzyme patterns in vegetative vs flowering plants}

The peroxidase isoenzyme patterns of the soluble peroxidase fraction from leaves taken from the most apical internodes of vegetative and flowering plants were analyzed by horizontal discontinuous starch-gel electrophoresis and stained with o-dianisidine as substrate. The results (fig 1 ) illustrated the presence of 3 groups of peroxidase isoenzymes expressed differentially during the development of the leaves. Thus, in vegetative plants, the development of the leaves was accompanied by an increase in the intensity of both the prx $a$ and the prx $b$ peroxidase isoenzyme groups (fig $1 \mathrm{~A}$ ), while in flowering plants the development of the leaves was accompanied by a decrease in the activity of both the prx $b$ group and the $p r x c_{1}$, followed by an increase in the activity of both the prx a group and the prx $c_{2}$ in the most basal leaves of flowering plants (fig 1B). Thus, peroxidase isoenzyme patterns changed with the development of the leaves in both vegetative and flowering plants.

These changes in peroxidase isoenzyme patterns were not organ-specific since peroxidase gradients along the stems in vegetative (fig 2) and flowering (data not shown) plants were also accompanied by the differential and specific expression of the abovementioned peroxidase isoenzyme groups. Thus, in vegetative plants (fig $3 A$ ), stem

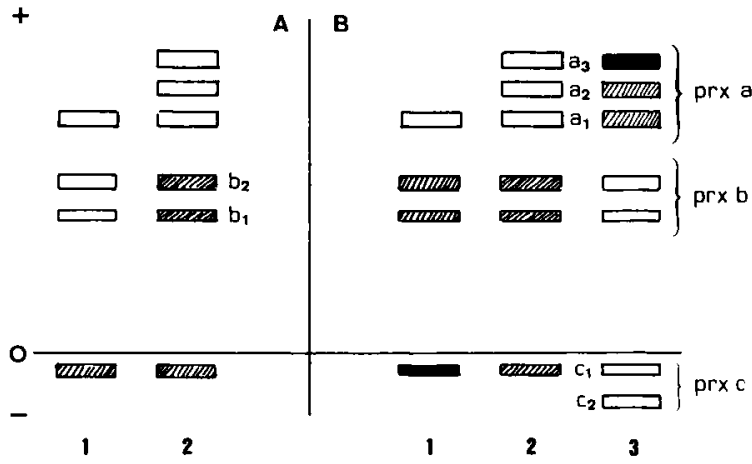

Fig 1. Leaf peroxidase isoenzyme patterns of soluble peroxidase activity extracted from vegetative $(A)$ and flowering (B) Capsicum plants, after staining with o-dianisidine, for leaves from the first (lane 1), second (lane 2), and fourth (lane 3) internodes. Comparative banding intensity is indicated by the degree of shading.

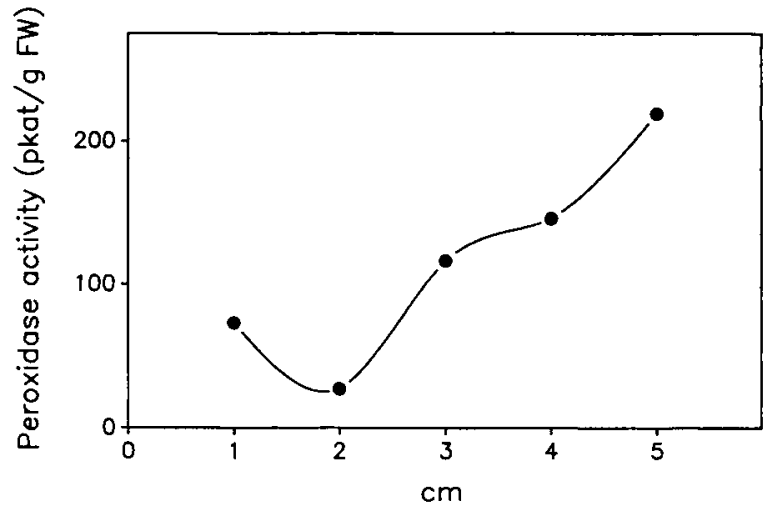

Fig 2. Level of soluble peroxidase activity measured with guaiacol in stems of vegetative Capsicum annuum as a function of the distance from the apex. Values are means $(n=3)$. Errors were within $5 \%$.

development was accompanied by a decrease in the activity of the peroxidase isoenzyme groups $p r x b$ and prx $c$, which was in turn accompanied by a strong increase in the $p r x$ a peroxidase isoenzyme group (fig $3 A$ ). Similar results were obtained for peroxidase isoenzyme gradients in stems of flowering plants (fig 3B).

These results suggests that during both leaf (fig 1) and stem (fig 3) development in vegetative and flowering plants a differential expression of peroxidase isoenzyme groups took place. This differential expression was characterized by an increase in the prx $b$ and prx $c$ peroxidase isoenzyme groups in young tissues of vegetative and flowering plants, which was followed by a decrease in the activity of the peroxidase isoenzyme groups

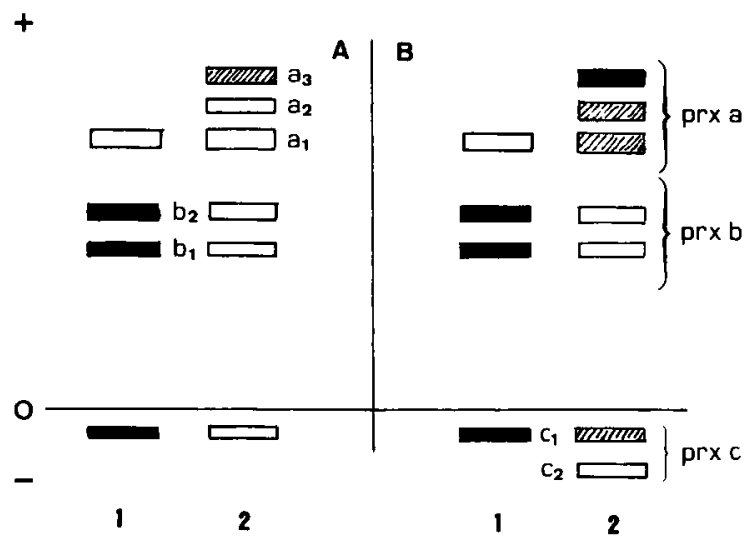

Fig 3. Stem peroxidase isoenzyme patterns of soluble peroxidase activity extracted from vegetative (A) and flowering $(B)$ Capsicum plants, after staining with o-dianisidine. Lane 1 corresponds to the first $\mathrm{cm}$ beneath the apex, whereas lane 2 corresponds to the last $\mathrm{cm}$ beneath the apex and continguous to the roots. Comparative banding intensity is indicated by the degree of shading. 
$p r x b$ and $p r x c_{1}$, this being accompanied by a strong increase in the activity of both the prx a group and prx $c_{2}$ in older tissues from both vegetative and flowering plants.

A similar sequential expression of peroxidase isoenzyme groups took place during the growth cycle of suspension cultured leaf pepper cells (Cuenca et al, 1989). However, unlike that observed in pepper cells cultured in vitro (Cuenca et al, 1989), the alteration in the peroxidase isoenzyme patterns in vegetative and flowering plants along the aging axis appear to be of post-translational nature (ie modification of the carbohydrate side chain of the peroxidase glycoprotein), since peroxidase isoenzyme patterns obtained along the same aging axis by isoelectric focusing showed only minor differences (Bernal et al, 1993). It must be pointed out that the separation of peroxidase isoenzymes according to their isoelectric points did not take into account their molecular weight but only the balance between acidic and basic amino-acid residues of the protein skeleton, which are the real determinants of the primary structure of the glycoproteins.

In fact, Hendriks and van Loon (1990) have reported that changes in peroxidase isoenzymes during leaf development was caused by differences in the terminal $\alpha$-linked mannose residues of the peroxidase glycoprotein. Likewise, Gaudreault and Tyson (1988) also reported that the heterogeneity of flax isoperoxidases was suppressed by digestion with $\alpha$-mannosidase.

\section{Subcellular localization of the peroxidase isoenzyme groups prxa, prx b and prxc}

From the above results, it can be concluded that peroxidase isoenzyme groups from the non-sedimentable peroxidase fraction are differentially expressed during the development of leaves in flowering and vegetative plants. The main subcellular origin of soluble (non-sedimentable) peroxidase activity in pepper leaves was the free space of the cell wall (Bernal et al, 1993). In this space, peroxidase activity, moving freely in cell walls was usually in equilibrium with that found ionically bound to the cell walls (Ros Barceló et al, 1988, 1989; Bernal et al, 1993).

The presence of the peroxidase isoenzyme groups prx $a, p r x b$ and prx $c$ in the free space of the cell wall of Capsicum annuum leaves in equilibrium with those found ionically bound to cell walls was confirmed by the use of the vacuum infiltration technique. Using this technique, it was possible to detect all the peroxidase isoenzyme groups in the free-space of the cell-wall extracted with buffer and in the enzyme fraction ionically bound to the cell walls (fig 4). Since $\mathrm{CaCl}_{2}$ removes both free-space and ionically bound cell-wall peroxidase activity (Ros Barceló et al, 1988; Bernal et al, 1993), it may be concluded that the increase in the isoenzyme activity observed after extraction with buffer containing $\mathrm{CaCl}_{2}$ (fig 4, lane 2), corresponds to the real activity bound in vivo to cell walls. This lends support to previous reports (Ros Barceló et al, 1988; Ferrer et al, 1992; Bernal et al, 1993) that peroxidase isoenzyme groups bound ionically to cell walls are in equilibrium with those present in the free space of the cell wall.

Furthermore, in the solution of the free space of the cell wall obtained for peroxidase isoenzyme analysis, it was also possible to detect $\alpha$-mannosidase, whose levels increased with leaf development (fig 5). These results are consistent with the suggestion that $\alpha$-mannosidase may be responsible for peroxidase heterogeneity induced during the development of the leaves.

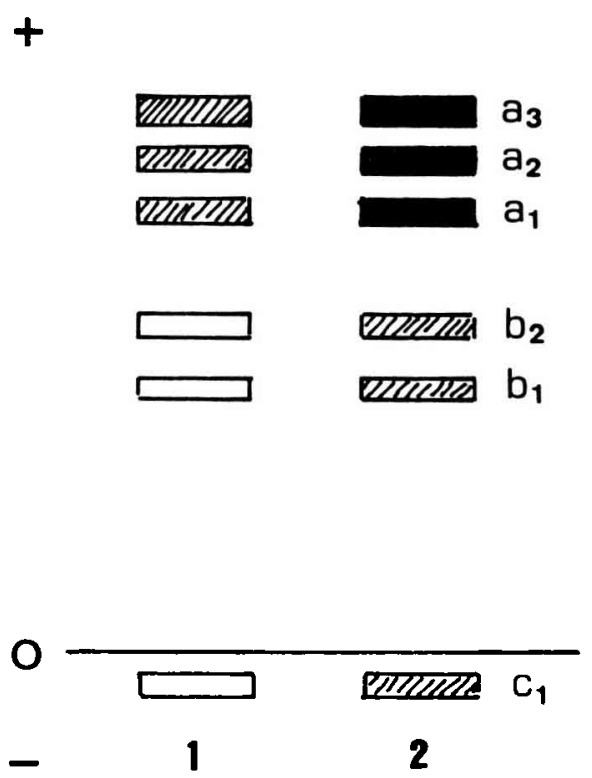

Fig 4. Peroxidase isoenzyme patterns of peroxidase activity extracted from free spaces of the cell wall with buffer (lane 1) and buffer containing $\mathrm{CaCl}_{2}$ (lane 2) of leaves from the fourth internode beneath the apex of flowering Capsicum plants, after staining with o-dianisidine. Comparative banding intensity is indicated by the degree of shading. 


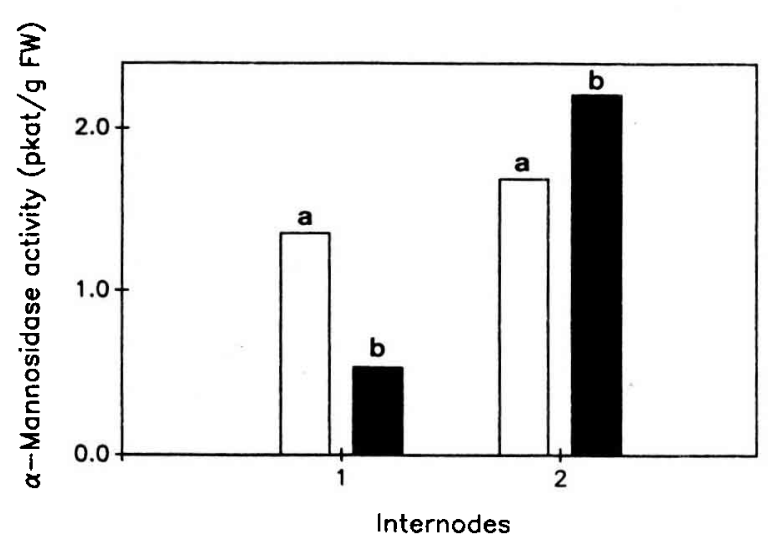

Fig 5. Levels of $\alpha$-mannosidase activity in leaf tissues after extracting the cell-wall free-space enzyme (a) and that recovered from the cell-wall free spaces (b) in leaves from the first and second internodes from vegetative Capsicum plants. Values are means $(n=3)$. Errors were within $5 \%$.

\section{Peroxidase activity gradients in vegetative vs flowering plants}

Due to the fact that the prx $a, p r x b$ and $p r x$ $c$ peroxidase isoenzyme groups are located in both the ionically bound cell-wall fraction and the free-space cell-wall fraction (fig 4), the level of peroxidase activity in these fractions in leaves from vegetative and flowering plants was studied as a function of leaf position along the internodes. The results showed that in vegetative plants the development of the leaves was accompanied by an increase in peroxidase activity in both the free-space of the cell-wall and the ionically bound cellwall fraction (fig 6). In the case of flowering plants, this increase in cell-wall-bound and cell-wall free-space peroxidase was accompanied by a decrease in the level of intracellular peroxidase (fig 7 ).

These results suggest that the increases in peroxidase activity ionically bound to cell walls and in the cell-wall free spaces as a consequence of leaf development in flowering Capsicum annuum plants (fig 7) were mainly due to the expression of the isoenzyme group prx a (fig 1). The increase in activity of this group in leaves from flowering plants, although related to leaf age since the increases were dependent on the leaf position along the internodes (fig 1), were not organ-specific since they were also expressed in older tissues of the stem from both vegetative and flowering plants (fig 3 ).

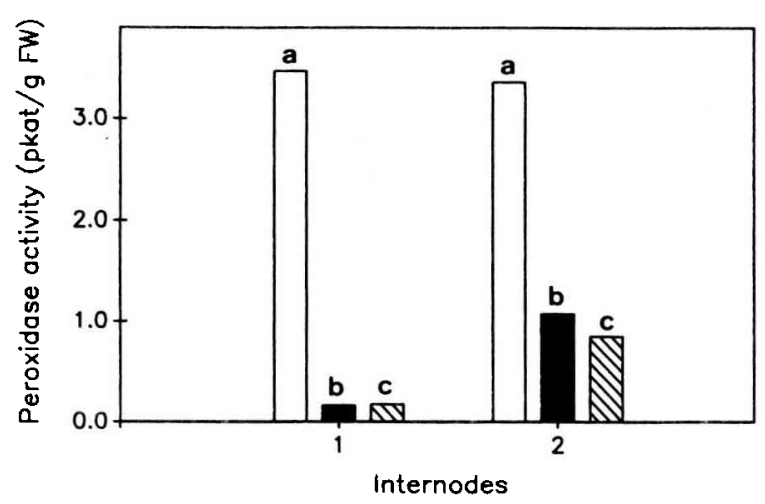

Fig 6. Levels of peroxidase activity in leaf tissues after extracting the cell-wall enzyme (a), ionically bound to cell walls (b), and recovered from the cell wall free spaces (c) in leaves from the first and second internodes from vegetative Capsicum plants. Values are means $(n=3)$. Errors were within $5 \%$.

The most important point raised here concerns the role performed by the observed increase in the prx a group in older tissues of flowering plants. In this context, it is well known that anionic (acidic) peroxidases catalyze the oxidation of coniferyl alcohol more efficiently than cationic (basic) peroxidases (Ferrer et al, 1992). This reaction may be partly coupled with auxin catabolism (Ferrer et al, 1990). In fact, since the peroxidase isoenzyme group prx $a$ is located in the cellwall space, and it is in this space that auxin catabolism mainly appears to take place (Ros Barceló and Muñoz, 1992), it might be suspected that an increase in this peroxidase isoenzyme group may be responsible for lowering auxin levels in leaves of both vegetative and flowered plants.

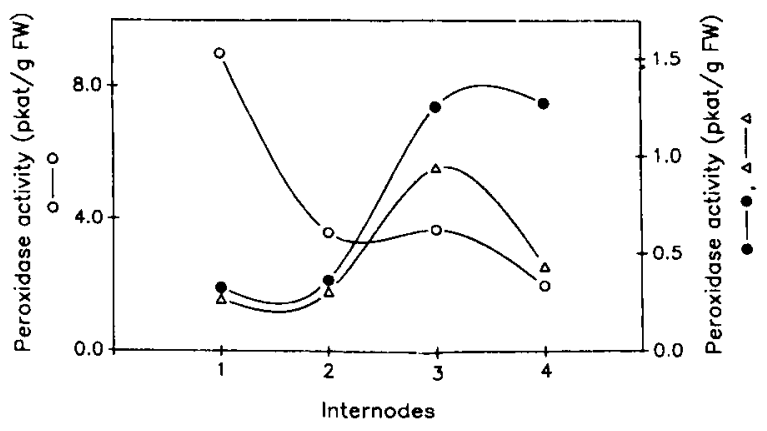

Fig 7. Levels of peroxidase activity in leaf tissues after extracting the cell-wall enzyme (O), ionically bound to cell walls (-), and recovered from the cell-wall free spaces $(\triangle)$ in leaves from the first, second, third and fourth internodes from flowering Capsicum plants. Values are means $(n=3)$. Errors were within $5 \%$. 


\section{ACKNOWLEDGMENTS}

This work was supported by a grant to FMC from the Universidad de La Coruña. MAB holds a fellowship from the Xunta de Galicia.

\section{REFERENCES}

Bernal MA, Pedreño MA, Calderón AA, Muñoz R, Ros Barceló A, Merino de Cáceres F (1993) The subcellular localization of isoperoxidases in Capsicum annuum leaves and their different expression in vegetative and flowered plants. Ann Bot 72, 415-421

Bernier G (1988) The control of floral evocation and morphogenesis. Annu Rev Plant Physiol, Plant Mol Biol 39, 175-219

Boller T, Kende H (1979) Hydrolytric enzymes in the central vacuole of plant cells. Plant Physiol $63,1123-1132$

Cuenca J, Garcia-Florenciano E, Ros Barceló A, Muñoz R (1989) Sequential release of both basic and acidic isoperoxidases to the media of suspension cultured cells of Capsicum annuum. Plant Cell Rep 8, 471-474

Driouich A, Gonnet P, Makkie M, Laine AC, Faye $L$ (1989) The role of high-mannose and complex asparagine-linked glycans in the secretion and stability of glycoproteins. Planta 180, 96104

Ferrer MA, Pedreño MA, Ros Barceló A, Muñoz $R$ (1990) Oxidation of coniferyl alcohol by cellwall peroxidases at the expenses of indole-3acetic acid and $\mathrm{O}_{2}$. A model for the lignification of plant cell walls in the absence of $\mathrm{H}_{2} \mathrm{O}_{2}$. FEBS Lett 276, 127-130

Ferrer MA, Pedreño MA, Ros Barceló A, Muñoz $A$ (1992) The cell wall localization of two strongly basic isoperoxidases in etiolated Lupinus albus hypocotyls and its significance in coniferyl alcohol oxidation and indole-3acetic acid catabolism. J Plant Physiol 139, 611-616

Gaudreault PR, Tyson H (1988) Elimination of differences in the mobility of flax isoperoxidases on PAGE by digestion with $\alpha$-mannosidase. Plant Physiol 86, 288-292

Gotô N, Hamada M (1988) Promotion of flowering by DNA base analogous and changes in acid phosphatase and peroxidase isoenzyme composition in dark-grown Arabidopsis thaliana. Plant Cell Physiol 29, 683-688
Greppin HR, Bonzon M, Crespi P, Crèvecœur M, Degli Agosti R, Penel C (1990) Physiological macrofunctions and indicators of the flowering process. In: Intra- and Intercellular Communications in Plants (B Millet, $\mathrm{H}$ Greppin, eds) INRA Press, Paris, 107-123

Hendriks T, van Loon LC (1990) The nature of the heterogeneity of petunia peroxidase a. J Plant Physiol 136, 526-531

Kahlem G (1975) A specific and general biochemical marker of stamen morphogenesis in higher plants: Anodic peroxidases. $Z$ Pflanzenphysiol $76,80-85$

Kay LE, Basile DV (1987) Specific peroxidase isoenzymes are correlated with organogenesis. Plant Physiol 84,. 99-105

Merino de Cáceres F, Bernal MA (1992) Estudio de la variabilidad isoenzimática en distintas poblaciones de pimiento de Padrón Capsicum annuum $\mathrm{L}$ var annuum. Nova Acta Cient Compostelana (Bioloxía) 3, 77-84

Rathmell WG, Sequeira L (1974) Soluble peroxidase in fluid from the intercellular spaces of tobacco leaves. Plant Physiol 53, 317-318

Ros Barceló A, Pedreño MA, Muñoz R, Sabater $F$ (1988) Lupin peroxidases. II. Binding of acidic isoperoxidases to cell walls. Physiol Plant 73, 238-244

Ros Barceló A, Muñoz R, Sabater F (1989) Subcellular location of basic and acidic soluble isoperoxidases in Lupinus. Plant Sci 63, 31-38

Ros Barceló A, Ferrer MA, García-Florenciano E, Muñoz R (1991) The tonoplast localization of two basic isoperoxidases of high pl in Lupinus. Bot Acta 104, 272-278

Ros Barceló A, Muñoz R (1992) Peroxidases: Their role in the control of plant cell growth. In: Peroxidases 1980-1990: Progress and Prospects in Biochemistry and Physiology (H Greppin, C Penel, T Gaspar, eds) University of Geneva, Geneva, 71-89

Takahama U, Egashira T (1991) Peroxidase in vacuoles of Vicia faba leaves. Phytochem 30, 73-77

Thorpe TA, Tran Thanh Van M, Gaspar T (1978) Isoperoxidases in epidermal layers of tobacco and changes during organ formation in vitro. Physiol Plant 44, 388-394

Trinh Th, Gaspar T, Tran Thanh Van K, Marcotte JL (1981) Genotype, ploidy and physiological state in relation to isoperoxidases in Nicotiana. Physiol Plant 53, 153-157

Zeevaart JAD (1976) Physiology of flower formation. Annu Rev Plant Physiol 27, 321-348 